Uniwersytet im. Adama Mickiewicza w Poznaniu UNIWERSYTET WARSZAWSKI

\title{
Wojna polsko-polska a kryzys postindustrialny
}

Dos OJĘCIE WOJNY POLSKO-POLSKIEJ, kojarzone przede wszystkim z wypowiedzią Andrzeja Wajdy w związku z katastrofą smoleńską, pojawiło się w polskim dyskursie politycznym już wcześniej i zostało użyte chociażby w artykule Wojna polsko-polska autorstwa Pawła Reszki i Michała Majewskiego, który ukazał się w gazecie „Dziennik Polska-Europa-Świat”. Szczególnej popularności nabrało ono jednak, co charakterystyczne, gdy Jarosław Kaczyński zapowiedział jej koniec na wiecu wyborczym w maju 2010 r. Od tego momentu kluczowa była nie tyle sama wojna, co chęć jej zakończenia. Mimo deklaracji pokojowych okazała się ona być jedynie w fazie zawieszenia broni, które to zawieszenie zakończyło się jeszcze w trakcie trwania wieczoru wyborczego. Nie zakończyło to jednak funkcjonowania tego terminu w polskim życiu publicznym, o czym może świadczyć np. użycie go przez Prezydenta RP Bronisława Komorowskiego w grudniu 2010 r. ${ }^{2}$

Jak widać pojęcie to za każdym razem było używane w kontekście politycznym i dotyczyło różnic ideologicznych między Platformą Obywatelską a Prawem i Sprawiedliwością. Rodzi się jednak kilka kluczowych pytań. Po pierwsze, czy owa wojna polsko-polska istnieje naprawdę, czy może jest tylko zgrabną figurą retoryczną, szczególnie przydatną podczas kampanii wyborczych? Po drugie, jakie są przyczyny wojny polsko-polskiej i co jest jej istotą? Po trzecie, dlaczego ujawniła się właśnie teraz? Wreszcie po czwarte, czy jest to zjawisko charakterystyczne jedynie dla Polski, czy może jest to jeden ze znaków czasu, w którym żyjemy, czy jest elementem czegoś większego? Trudno także nie zadać sobie pytania charakterystycznego dla wszystkich wojen - kto ją wygra oraz jak długo będzie ona trwała? Poszukiwanie

${ }^{1}$ M. Majewski, P. Reszka, Wojna polsko-polska, „Dziennik Polska-Europa-Świat” z dnia 18 lipca 2008, s. 1.

2 Nie zmieniam oceny Jaruzelskiego, Wiadomości, http://www.tvn24.pl/-1,1685998,o,1,komorowski-nie-zmieniam-oceny-jaruzelskiego,wiadomosc.htm, 13.03.2011 r. 
odpowiedzi na tak sformułowane pytania stało się przedmiotem rozważań w niniejszym opracowaniu.

Wojna polsko-polska wydaje się być zjawiskiem prawdziwym, a jej przyczyn należy upatrywać w wielkim cywilizacyjnym kryzysie, który towarzyszy przejściu z epoki industrialnej do postindustrialnej. Kryzys ten trwa nie tylko w Polsce, ale w całej zachodniej cywilizacji, natomiast jego skutki promieniują na cały współczesny świat.

Czym jest sam kryzys postindustrialny? Określenie „kryzys” oznacza punkt zwrotny, przełom i wiąże się z terminem zmiany społecznej. Kojarzyć je zatem należy z socjologią dynamiczną, czyli orientacją traktująca społeczeństwo jako twór dynamiczny podlegający zmianom w skutek zachodzących z nim procesów ${ }^{3}$.

O ile najwybitniejsi filozofowie, socjolodzy i antropolodzy nie mają wątpliwości, że kryzys dotyczy współczesnych społeczeństw, to często posługują się innym aparatem pojęciowym i zwracają uwagę na inne jego aspekty. Różnice ujawniają się już przy nazywaniu epok i co za tym idzie kryzysu, który towarzyszy przejściu z drugiej do trzeciej epoki. Alvin Toffler mówi o drugiej i trzeciej fali, natomiast Anthony Giddens mówi o nowoczesności i ponowoczesności podobnie jak Zygmunt Bauman, jednakże różnią się oni m.in. co do diagnozy momentu, w którym obecnie się znajdujemy. Kolejne określenie, szczególnie popularne wśród polskich autorów, bierze się od pioniera teorii społeczeństwa postindustrialnego Daniela Bella, który wyróżnia odpowiednio industrializm oraz postindustrializm. Z kolei cechy wspólne to kompleksowe podejście do kryzysu, czyli pogląd, iż kryzys dotyka wszystkich wymiarów ładu społecznego oraz zgoda co do powszechności kryzysu - dotyczy ona zarówno wielkich struktur społecznych, jak i poszczególnych jednostek. Różnice natomiast, rzecz jasna, nie sprowadzają się tylko do różnych nazw.

Przejdźmy zatem do szczegółów - A. Toffler szczególną uwagę przywiązuje do ładu gospodarczego oraz zmian technologicznych. Przyczyn poszczególnych kryzysów, jak i cezur kolejnych epok upatruje on więc przede wszystkim w kwestiach ekonomicznych. Wyróżnia trzy przewroty społeczne, które towarzyszyły zmianom epok. Pierwszą falą była epoka rolnicza, drugą falą epoka przemysłowa, natomiast trzecią falą jest epoka, w którą wkraczamy ${ }^{4}$. Pierwsza fala rozpocząć się miała wraz z osiadłym trybem życia człowieka w wyniku rozwoju rolnictwa,

${ }^{3} \mathrm{~K}$. Wielecki, Podmiotowość $w$ dobie kryzysu postindustrializmu, Warszawa 2003, S. 109.

${ }^{4}$ A. Toffler, Trzecia fala, Warszawa 1997, s. 35-36. 
co zdarzyło się około 10 tysięcy lat temu. Początkiem drugiej fali była rewolucja przemysłowa (1650-1750 r.), natomiast początkiem trzeciej fali jest rewolucja superprzemysłowa, utożsamiana z rewolucją w obszarze przepływu informacji i elektroniki (dla Stanów Zjednoczonych -1955 r.) $)^{5}$. A. Toffler zwraca uwagę na znaczne przyspieszenie zachodzących zmian - cywilizacja pierwszej fali przetrwała tysiące lat, drugiej fali już tylko 300 lat. Możemy się więc spodziewać, że kolejna fala powinna nastąpić już za kilkadziesiąt lat ${ }^{6}$. Wśród kluczowych obszarów przemian związanych z nadejściem trzeciej fali wymienia on rozpad rodziny, zachwianie gospodarki, paraliż systemów politycznych, nowy styl życia oparty na zróżnicowanych, odnawialnych źródłach energii i nowych metodach produkcji. Cywilizacja trzeciej fali obali biurokrację, ograniczy znaczenie państwa narodowego. Wszystko to wymusi nowe, skromniejsze i efektywniejsze formy rządzenia. Szczególnie podkreślone zostało wyeliminowanie dystansu pomiędzy producentami a konsumentami i wynikające z tego stworzenie gospodarki prosumentów, co według A. Tofflera ma ogromne znaczenie, z uwagi na zakładany przez niego determinizm technologiczno-ekonomiczny Ponadto, trzecia fala związana jest m.in. z szerokim zastosowaniem komputerów, powszechnością lotów pasażerskich czy popularnością pigułki antykoncepcyjnej ${ }^{8}$.

Zmiany zachodzące w związku z przypływem fali mają mieć charakter kumulatywny, czyli dotykają wszystkich sfer naszego życia. Zakłada on także, że zmiany te nie są chaotyczne oraz cechują się gwałtownościąa. Sposób modelowania przyjęty w Trzeciej fali opiera się o analizę frontalną, zgodnie z którą każdej fali należy przyjrzeć się pod kątem krawędzi natarcia. Na tej podstawie możemy określić, gdzie dana fala poniesie określoną cywilizację ${ }^{10}$.

Według A. Tofflera pierwsza fala, czyli ta związana z rewolucją agrarną i rozpoczęciem osiadłego trybu życia praktycznie już nie występuje, wyjąwszy niewielkie społeczności plemienne żyjące np. w Pa-

${ }^{5}$ Ibidem, s. 43-44.

${ }^{6}$ Ibidem, s. 44.

7 Ibidem, s. 44-45.

${ }^{8}$ Ibidem, s. 50. Nie bez znaczenia jest fakt, że na jedną z najpopularniejszych bitew wojny polsko-polskiej, zwolennicy trzeciej fali zorganizowali się za pośrednictwem portali społecznościowych. „Akcja krzyż”: cyrk udat się. Sześć osób trzeźwieje, http://www.tvn24.pl/-1,1668615,0,1,akcja-krzyz-pod-palacem-cyrk-udal-sie,wiadomo sc.html, 30.03.2011 r.

${ }_{9}^{9}$ A. Toffler, Trzecia..., op. cit., s. 47.

${ }^{10}$ Ibidem, s. 48. 
pui-Nowej Gwinei. Druga fala, która przyszła wraz z rewolucją przemysłową rozprzestrzenia się jeszcze po świecie i występuje w państwach, które dopiero zaczynają budować wielkie zakłady przemysłowe. Proces związany z przybyciem trzeciej fali dopiero się rozpoczął. Fale, mimo że możemy wskazać epoki, w których dominują bądź dominowały, nachodzą się na siebie i zderzają powodując w ten sposób olbrzymie napięcia społeczne i polityczne, które są istotą „Superwalki”. Za związany z przypływem trzeciej fali objaw „Superwalki” A. Toffler wskazuje rok 1955 w Stanach Zjednoczonych, gdy pracownicy umysłowi i usługowi, czyli tzw. „białe kołnierzyki”, osiągnęli przewagę nad pracownikami fizycznymi - „niebieskimi kołnierzykami” ${ }^{11}$. Dla porównania w Polsce ostatnim rokiem równowagi zatrudnienia białych i niebieskich kołnierzyków był rok 1989, kiedy to w rolnictwie pracowało $28,6 \%$ natomiast w przemyśle i usługach po $35,7 \%$. W roku $1991 \mathrm{w}$ rolnictwie pracowało $26,8 \%$, w przemyśle $35 \%$, zaś w usługach już $38,2 \%{ }^{12}$.

Wprowadzone przez A. Tofflera pojęcie „Superwalki” znacząco ułatwi nam analizę wojny polsko-polskiej, która wydaje się być kolejną odsłoną tego, co zdarzyło się w latach pięćdziesiątych w Stanach Zjednoczonych.

Gdy jednak dojdzie już do „Superwalki”, można dosyć łatwo określić kierunek przemian - kolejna fala zawsze odnosi zwycięstwo. Przykładem może być nadejście drugiej fali i pewność nadchodzącego rozwoju technologicznego, gwałtownego rozwoju miast, szybszego transportu i masowej oświaty. Wraz z tymi zmianami przyszły gwałtowne przemiany procesów politycznych, na co przygotowywały się rozmaite ruchy polityczne. Ruchy związane z przedprzemysłowym rolnictwem sprzeciwiały się „wdzierającemu się industrializmowi” oraz upadkowi moralnemu istniejącemu według nich w miastach. Robotnicy natomiast rozpoczęli walkę o wpływy oraz zgłaszali chęć udziału w kreowaniu nowego porządku opartego na przemyśle ${ }^{13}$. Trudności w modelowaniu mogą się jednak pojawić, gdy wystąpi klincz, czyli wyrównana walka pomiędzy drugą a trzecią falą. Znacznie trudniej jest wtedy określić kierunek przemian, dochodzi do nietypowych aliansów, napięć społecznych i konfliktów idących w poprzek tradycyjnym podziałom, takim jak podziały warstwowo-klasowe, rasowe, politycz-

${ }^{11}$ Ibidem, s. 47-48.

${ }_{12}$ B. Puzio-Wacławik, Przeobrażenia trójsektorowej struktury zatrudnienia w Polsce, na tle doświadczeń krajów Unii Europejskiej, [w:] Wykorzystanie zasobów pracy we współczesnej gospodarce, red. D. Kopycińskiej, Szczecin 2007, s. 72.

${ }^{13}$ A. Toffler, Trzecia..., op. cit., s. 35-36, s. 51. 
ne czy religijne. Dezaktualizują się wszelkie koalicje i wojny. A. Toffler przywołuje tu przypadek wzajemnej niechęci Murzynów i Żydów w USA, którzy wcześniej szli ramię w ramię przeciw dyskryminacji, czy nietypowy alians związkowców z ruchami ochrony środowiska naturalnego. Ruchy robotnicze, wcześniej uchodzące za postępowe, odchodzą od haseł równouprawnienia kobiet, zmian w funkcjonowaniu rodziny, otwartości na imigrantów, polityki celnej czy decentralizacji. Lewica trzeciej fali to często zwolennicy centralizacji państwa, przeciwnicy ochrony środowiska i nacjonaliści. Na poparcie tej tezy A. Toffler przywołuje przykład Jimmiego Cartera i jego konserwatywny stosunek do gospodarki oraz liberalny do praw kobiet czy ochrony środowiska. Ten pozorny brak logiki w życiu publicznym owocuje dezintegracją osobowości i poczuciem zagubienia wśród obywateli ${ }^{14}$. Spośód polskich przykładów można wymienić kryzys lewicy, a w szczególności medialną koalicję Sojuszu Lewicy Demokratycznej z Prawem i Sprawiedliwością czy powstanie ruchów społecznych takich jak Koliber (Konserwatywni Liberałowie). Skutki tego klinczu mogą dotyczyć nie tylko zmian w całych ruchach społecznych, ale także decyzji pojedynczych uczestników życia publicznego np. zadeklarowanie sympatii do Prawa i Sprawiedliwości przez Jadwigę Staniszkis.

„Superwalka” jest zatem świetnym wytłumaczeniem pozornie nielogicznych sporów i napięć pomiędzy partiami politycznymi, które próbują, często nie znając przyczyn tego zjawiska, jak najwięcej z tych przemian przekuć na polityczny kapitał. A. Toffler zauważa jednak, że w „Superwalce” nie jest istotne, kto będzie odgrywał decydującą rolę w ustępującej drugiej fali, ale kto będzie kształtował cywilizację trzeciej fali ${ }^{15}$.

W związku z tym, że wojna polsko-polska ma przede wszystkim wymiar polityczny, zasadne wydaje się wykazanie różnic w poglądach politycznych poszczególnych fal i zastanowienie się nad ich przełożeniem na poszczególne strony tego konfliktu. W dalszej części artykułu starano się dowieść, że wojna polsko-polska toczącą się pomiędzy Platformą Obywatelską a Prawem i Sprawiedliwością jest w dużej mierze „Superwalką”, gdzie drugą falę reprezentują środowiska związane z PiS, zaś trzecią falę PO, a raczej ruchy społeczne „antyPiS”. Na potrzeby niniejszego artykułu w przypadku drugiej fali skupiono się przede wszystkim na największych graczach poszczególnych fal, czyli

\footnotetext{
${ }^{14}$ Ibidem, s. 51-53.

15 Ibidem, s. 54.
} 
PiS i PO. Warto jednak podkreślić, że w ramach drugiej fali występuje wiele innych ruchów społecznych jak chociażby środowiska skupione wokół „Naszego Dziennika” czy „Gazety Polskiej”. W przypadku trzeciej fali niektóre z tych innych środowisk z uwagi na specyfikę postindustrializmu niechętnie się organizują, ale występują w dyskursie publicznym, często $\mathrm{w}$ ramach jednorazowych akcji, np. organizatorzy zgromadzenia Akcja Krzyż pod pałacem prezydenckim w Warszawie.

Druga fala wyrosła wokół powstania nowych instytucji społecznych: rodziny nuklearnej, masowej edukacji oraz publicznych i prywatnych korporacji. Zmiany w rodzinach wiązały się ze zmianą roli rodziny w gospodarce - rodzina nie była już jednostką gospodarczą wskutek odejścia od pracy w rolnictwie na rzecz pracy w przemyśle. Osłabieniu uległa rola ojca, zmienił się stosunek dzieci do rodziców, a z czasem pojawiły się nowe obyczaje. W związku z koniecznością oddania całego czasu fabryce, powstały instytucje, które przejęły różne funkcje rodziny. Wychowaniem zajęła się szkoła czy opieką nad starszymi - domy spokojnej starości. Rodziny musiały być także mobilne - gotowe do przeprowadzek z miejsca na miejsce, wszak dające pracę zakłady przemysłowe znajdowały się głównie w dużych miastach. Wszystko to spowodowało odejście od modelu dużych, wielopokoleniowych rodzin na rzecz rodzin nuklearnych składających się z rodziców i kilkorga dzieci ${ }^{16}$.

Szkoła, zdaniem A. Tofflera, miała nie tylko odciążyć zapracowanych rodziców, ale także przygotować ich do pracy w fabrykach. Pod płaszczykiem zdobywania umiejętności, takich jak liczenie, czytanie czy pisanie miała ona wpajać takie cechy jak punktualność, posłuszeństwo i umiejętność wykonywania rutynowej pracy ${ }^{17}$.

Trzecią instytucją społeczną drugiej fali były korporacje, zarówno prywatne, jak i publiczne. Powstanie korporacji wynikało z pojawienia się produkcji masowej. Założenie fabryki znacznie przerastało możliwości pojedynczych osób. Stąd powstała potrzeba nowych formuł prawnych dla działalności gospodarczej industrialnego człowieka. Korporacja była właśnie taką formuła, która z jednej strony umożliwiała kumulację kapitału niespotykanej wcześnie liczby osób oraz ograniczenie ryzyka do wysokości zainwestowanych w przedsięwzięcie pieniędzy. Firmy przestały być już kojarzone z konkretnymi właścicielami, których nota bene często przeżywały, natomiast inwestorzy

\footnotetext{
${ }^{16}$ Ibidem, s. 68-69.

${ }^{17}$ Ibidem, s. 70.
} 
zaczęli być bardziej skłonni do dużych i ryzykownych przedsięwzięć, co w konsekwencji prowadziło do ograniczenia odpowiedzialności do włożonego kapitału ${ }^{18}$.

Wymienione trzy instytucje - rodzina nuklearna, masowa edukacja i korporacje, organizowały życie społeczne od urodzin, aż do śmierci i decydowały o ustroju całych społeczeństw. Możemy to zaobserwować w znaczeniu, jakie Prawo i Sprawiedliwość przykłada w deklarowanych wartościach do rodziny czy cech promowanych przez industrialną edukację takich jak posłuszeństwo czy troska o ludzi wykonujących rutynową pracę. Tłumaczy to wodzowski charakter partii, posłuszeństwo wobec państwa (prawo w nazwie, czy hasło kampanii prezydenckiej z 2010 r. - „Polska jest najważniejsza”) oraz adresowanie programu do osób pracujących w zawodach polegających na wykonywaniu rutynowej pracy. Objawia się to także przywiązaniem do dużych zakładów przemysłowych takich jak stocznie czy instytucji wyrosłych przy korporacjach takich jak związki zawodowe.

Przychylność do związków zawodowych ma także swoje korzenie, poza wymienioną już tendencją do przyjmowania postaw nacjonalistycznych przez ruchy robotnicze, dla których w oczywisty sposób wspólnym mianownikiem jest „Solidarność”, we wzroście znaczenia rynku jako takiego w życiu społecznym, a co za tym idzie, także w życiu publicznym. Hasła o charakterze ekonomicznym zaczęły dominować dyskurs publiczny, co wcześniej nie miało miejsca, przynajmniej na taką skalę. Naturalnym aktorem politycznym wysuwającym takie żądania są właśnie związki zawodowe ${ }^{19}$.

Na wymienione główne instytucje społeczne każdej fali nakłada się charakterystyczny dla niej zbiór reguł i zasad, który A. Toffler nazywa „utajonym szyfrem” i wskazuje, że „Superwalka”, odbywa się poprzez instynktowne popieranie wartości przez zwolenników ustępującej fali i kwestionowanie ich przez zwolenników nadchodzącej fali ${ }^{20}$. Zrozumienie szyfrów staje się zatem kluczem do zrozumienia „Superwalki”, a co za tym idzie, także jej polskiej odsłony, czyli wojny polsko-polskiej. Szyfr ten, w przypadku drugiej fali to standaryzacja, specjalizacja, synchronizacja, koncentracja, maksymalizacja i centralizacja ${ }^{21}$.

Przyczyn pojawienia się standaryzacji również należy upatrywać w wielkiej rewolucji przemysłowej i rozwoju produkcji masowej.

\footnotetext{
${ }^{18}$ Ibidem, s. 72.

${ }^{19}$ Ibidem, s. 85 .

${ }^{20}$ Ibidem, s. 93.

${ }^{21}$ Ibidem, S. 113.
} 
A. Toffler wskazuje, iż standaryzacja, która najpierw przejawiała się ujednoliceniem organizacji pracy, była równie popularna u kapitalistów jak i komunistów. Wspólnym mianownikiem była myśl Frederica Winslowa Taylora, który był inicjatorem standaryzacji czynności pracy i naukowego podejścia do mierzenia jej efektywności ${ }^{22}$. Standaryzacja następnie objęła kolejne obszary działalności gospodarczej, takie jak nabór pracowników, sposób wynagradzania za pracę, przerwy obiadowe czy procedura rozpoznawania skarg i wniosków. Wreszcie standaryzacja opuściła obszar aktywności ekonomicznej i pojawiła się także w procedurze przyjmowania uczniów do szkół, weryfikacji ich wiedzy poprzez egzaminy testowe czy promowanie absolwentów, po to by wreszcie zaistnieć w ludzkich umysłach. Ludzie zaczęli się upodabniać do siebie, chociażby w wyniku czytania tych samych gazet $^{23}$. Konsekwencją tego rozpowszechniania się standaryzacji okazała się być niechęć dla odmiennego stylu myślenia i zachowania. To między innymi stąd bierze się w PiS niechęć do mniejszości, w tym środowisk homoseksualnych.

Kolejną zasadą obowiązującą w społeczeństwach drugiej fali jest specjalizacja. Specjalizacja pojawiła się wraz ze standaryzacją. Odtąd pracownik miał wykonywać mniej czynności, ale znacznie efektywniej ${ }^{24}$. Wraz ze specjalizacją pojawiła się także profesjonalizacja. Pojawiały się nowe zawody, powstałe w skutek zmonopolizowania przez dane grupy zawodowe swojej wiedzy, profesjonalizacji zawodu polity$\mathrm{ka}^{25}$. Podręcznikowym wręcz przykładem jest zakwestionowanie przez Jarosława Kaczyńskiego prawa do udziału w debacie publicznej o katastrofie smoleńskiej Adamowi Małyszowi ${ }^{26}$.

Postępująca standaryzacja i specjalizacja wymusiła synchronizację, która zmieniła podejście do czasu całego społeczeństwa. Przy tak dużym podziale pracy najmniejsze spóźnienie hamowało pracę w całym zakładzie i właśnie dlatego w szkołach wpajana była punktualnośćc ${ }^{27}$. Synchronizacja nie ograniczała się tylko do koordynacji prac, ale także zaczęła przenikać do organizacji czasu wolnego ${ }^{28}$. Przekonanie o standardowych dniach wolnych od pracy, czyli micie założyciel-

\footnotetext{
${ }^{22}$ Ibidem, s. 94-95.

${ }^{23}$ Ibidem, s. 95-96.

${ }^{24}$ Ibidem, s. 97.

${ }^{25}$ Ibidem, s. 99.

${ }^{26}$ Prezes PiS (nie) odpowiedziat Matyszowi, http://www.tvn24.pl/1,1696658,druk. html, 30.03.2011 r.

${ }^{27}$ A. Toffler, Trzecia..., op. cit., s. 100-101.

${ }^{28}$ Ibidem, s. 102.
} 
skim świąt państwowych i religijnych, możemy także odnaleźć w ruchach związanych z Prawem i Sprawiedliwością. Wydaje się, że jest to jedna z przyczyn, obok przywiązania do katolicyzmu, dla których to właśnie te ruchy zainicjowały debatę o ustanowieniu Święta Trzech Króli dniem wolnym od pracy. O specjalizacji i standaryzacji pisze także Z. Bauman. Jej symbolami ma być fordowska fabryka, która sprowadza działanie człowieka do prostych powtarzalnych czynności oraz biurokracja przypominający model weberowski, w której urzędnicy porzucają tożsamość i wykonują zadania ściśle zgodnie z procedura$\mathrm{mi}^{29}$.

W związku z rozwojem instytucji korporacji, które powstały wskutek konieczności kumulacji kapitału dla powstania dużych ośrodków przemysłowych zrodziła się zasada koncentracji. Koncentracja przejawiała się także w migracjach siły roboczej ze wsi do miast oraz skupienie się na energii pochodzącej z paliw kopalnych. Zmieniło się także podejście do ubogich, dla których zaczęto organizować przytułki, obłąkanych, którzy przeszli z garnuszka rodziny do domów dla psychicznie chorych, czy wreszcie do więźniów, których wcześniej karano chłostą, natomiast $\mathrm{w}$ społeczeństwach industrialnych zaczęto umieszczać ich na masową skalę $\mathrm{w}$ więzieniach ${ }^{30}$. Zasada koncentracji pozwala nam zatem wytłumaczyć przychylny stosunek Prawa i Sprawiedliwości do górników oraz opierania gospodarki na węglu, ale także wzmożoną chęć do penalizacji czynów zabronionych oraz aktywną politykę rządu w zakresie, nie tyle zmniejszania przestępczości, co walki z przestępczością (zmniejszanie przestępczości nie służy instytucji więzienia, natomiast walka z nią już tak). Doskonale widać to na przykładzie utworzenia Centralnego Biura Antykorupcyjnego, bazującego o wiele bardziej na prowokacjach i szeroko rozumianej działalności operacyjnej, a minimalizującego rolę prewencji i badań nad przyczynami korupcji. Z Centralnym Biurem Antykorupcyjnym związane są jeszcze dwa symbole industrializmu, o których wspomina Z. Bauman - Panopticon z wieżami strażniczymi i pensjonariuszami oraz Wielki Brat, który szybko i sprawnie wynagradza i karze ${ }^{31}$. Należy zwrócić uwagę, że aby można było sprawnie i szybko karać i nagradzać, niezbędna jest rezygnacja z demokratycznych procedur sądowniczych. Przejawiało się to w przypadku Prawa i Sprawiedliwości wydawaniem wyroków

\footnotetext{
${ }^{29}$ Z. Bauman, Ptynna nowoczesność, Kraków 2006, s. 41.

${ }^{30}$ A. Toffler, Trzecia..., op. cit., s. 105-106.

${ }^{31}$ Z. Bauman, Ptynna...,op. cit., s. 41.
} 
na konferencjach prasowych, jak działo się to w sprawie Mirosława Garlickiego.

Następną zasadą obowiązująca w cywilizacji drugiej fali jest maksymalizacja i upodobanie do rzeczy wielkich. Przykładem funkcjonowania tej zasady w polityce Prawa i Sprawiedliwości, może być zebranie niemal miliona siedmiuset tysięcy podpisów pod zgłoszeniem kandydata Jarosława Kaczyńskiego na Prezydenta RP, czyli prawie siedemnaście razy więcej niż wynika to z ustawy z dnia 27 września 1990 r. o wyborze Prezydenta Rzeczypospolitej Polskiej ${ }^{32}$. Oczywiście przyczyn tego zjawiska można upatrywać także w dużym zaangażowaniu elektoratu Prawa i Sprawiedliwości oraz większym utożsamianiu się jego sympatyków z partią niż działo się to w przypadku innych kandydatów.

Ostatnią już zasadą, szczególnie istotną z punktu widzenia procesów i zjawisk o charakterze politycznym, jest centralizacja. Patrząc przez pryzmat wcześniejszych zasad wydaje się być wręcz ich częścią. A. Toffler przywołuje przykład menadżerów kolejowych, którzy najpierw musieli zestandaryzować technikę przewozu - od taryf po rozkłady jazdy - następnie zsynchronizować przewozy ze sobą, powołać nowe specjalistyczne zawody, skoncentrować kapitał, energię i ludzi oraz zmaksymalizować zasięg linii kolejowych. Aby móc to wszystko osiągnąc musieli zcentralizować swoją organizację oraz ją zhierarchizować, podzielić pracowników na kadrę kierowniczą i szeregowych pracowników ${ }^{33}$.

A. Toffler zaprezentował także parę przykładów centralizacji w działalności politycznej industrialnego człowieka. Wymienia on konstytucję Stanów Zjednoczonych, która zastąpiła Artykuły Konfederacji, centralizację władzy publicznej czy instytucję banku centralnego ${ }^{34}$. Świetnym przykładem urzeczywistnienia zasady centralizacji w programie PiS jest projekt Konstytucji Rzeczypospolitej Polskiej, zgodnie z którym Prezes Rady Ministrów dysponuje pełnią władzy wykonawczej, natomiast Prezydent nie ma być częścią władzy wykonawczej, ale stać ponad trójpodziałem władzy35.

${ }^{32}$ Dz. U. 1990 Nr 67, poz. 398 z późn. zm.

33 Ibidem, s. 108-109.

${ }^{34}$ Ibidem, s. 110-112.

${ }^{35}$ Zob. Projekt Prawa i Sprawiedliwości. Konstytucja Rzeczypospolitej Polskiej, http://www.pis.org.pl/download.php?g=mmedia\&f=konstytucja_2010.pdf, 28.03.2011 r., s. 7. 
A. Toffler zwraca także uwagę na problem techników władzy. W społeczeństwie drugiej fali nie można krótko odpowiedzieć na pytanie „Kto rządzi?”, ponieważ władzę sprawowali anonimowi „oni” ${ }^{36}$. Pojawiły się nowe elity kierownicze, które niekoniecznie posiadały środki produkcji w rozumienia Karola Marksa, natomiast sprawowały realną władzę i pełniły funkcję integracyjną jednostki, którą kierowały, a była ona przecież rozdrabniana chociażby przez daleko idący podział pracy ${ }^{37}$. Sprawowanie władzy przez anonimową grupę osób, bardzo mocno przeniknęło do polityki uprawianej przez PiS. Przywołać można chociażby takie określenia jak „układ” 38 , „wykształciuchy” („znaczna część warstwy wykształconej, która posiada pewną profesjonalną kompetencję, ale straciła kontakt z resztą Polski”) ${ }^{39}$, „łze-elity”40, które stały się polską wersją sformułowania używanego przez A. Tofflera „oni”.

Przystępując do opisywania trzeciej fali warto zaznaczyć, że druga fala jest znacznie łatwiejsza do opisania, z uwagi na to, że organizowała już społeczeństwo przez kilkaset lat, natomiast trzecia fala dopiero nadchodzi. Znajduje to także odzwierciedlenie w książce A. Tofflera, gdzie opis cywilizacji trzeciej fali nie jest już tak dokładny jak to się działo w przypadku drugiej fali, co nie pozostało bez znaczenia dla proporcji niniejszej pracy. Należy także wskazać, że zgodnie z wieloma poglądami socjologów i futurologów nie jesteśmy jeszcze w postindustrializmie, ale w późnej nowoczesności, która teraz jest w fazie radykalizacji, jednak stoimy już u progu ponowoczesności, jak twierdzi A. Giddens, bądź w płynnej nowoczesności, jak twierdzi Z. Bauman. Pogląd Z. Baumana wymaga jednak rozwinięcia. Początkowo w jego pracach dominowało pojęcie ponowoczesności, które z czasem zostało zastąpione płynną nowoczesnością. Jest ona nową fazą nowoczesności, a określenie płynna należy interpretować przez pryzmat jej lekkości i nieważkości, która warunkuje zmienność czasów płynnej nowoczesności ${ }^{41}$.

\footnotetext{
${ }^{36}$ A. Toffler, Trzecia..., op. cit., s. 115 .

${ }^{37}$ Ibidem, 115-116.

${ }^{38}$ Zob. Treść 2. posiedzenia Sejmu (Obrady $w$ dniu 10 listopada 2005 r.), Sejm Rzeczypospolitej Polskiej kadencja V, Warszawa 2005, s. 6.

39 J. Lichocka, Dorn: krytykuje nas rojowisko histeryków, „Dziennik Polska-Europa-Świat” z dnia 26-27 sierpnia 2006, s. 24.

${ }_{40}$ Zob. Sprawozdanie Stenograficzne z 10 posiedzenia Sejmu Rzeczypospolitej Polskiej $w$ dniu 17 lutego 2006 r. (trzeci dzień obrad), Sejm Rzeczypospolitej Polskiej kadencja V, Warszawa 2006, s. 267.

${ }^{41}$ Z. Bauman, Ptynna..., op. cit., s. 7.
} 
Należy zatem zauważyć, że „Superwalka” w dzisiejszych czasach będzie oznaczała nie tyle walkę drugiej fali z trzecią falą, ale walkę drugiej fali z harcownikami postindustrializmu, którzy przede wszystkim wątpią w poglądy zbudowane na podstawie industrializmu, ale jeszcze nie są w stanie tworzyć własnych w oparciu o postindustrializm istniejących jako typ idealny. Stąd drugą stronę wojny polsko-polskiej należy interpretować przez pryzmat drugiej fali, starając się jednak szukać pewnych zapowiedzi trzeciej fali.

Jak dla drugiej fali mitem założycielskim była produkcja masowa, tak dla trzeciej fali punktem wyjścia jest odmasowienie produkcji, a w konsekwencji całego społeczeństwa. Coraz mniejszą część produktu narodowego stanowi przemysł, zwiększa się natomiast udział usług, wymuszających dopasowanie do klienta. W konsekwencji trzecia fala rezygnuje ze standaryzacji na rzecz krótkich serii produktów przygotowywanych na częściowo albo całkowicie na zamówienie ${ }^{42}$. Per analogia do opisanych przykładów dla drugiej fali, odejście od standaryzacji nie pozostanie bez wpływu na ludzkie umysły, które będą bardziej przychylne różnorodności ${ }^{43}$. Stąd w Platformie Obywatelskiej pojawia się większa tolerancja dla środowisk homoseksualnych.

Zerwaniu ze standaryzacją sprzyja także włączenie klienta w produkcję, czyli zmiana roli z konsumenta w prosumenta. Przykładami działalności gospodarczej wykorzystującymi prosumpcję mogą być przywołane przez A. Tofflera testy ciążowe ${ }^{44}$, czy znane nam meble przeznaczone do samodzielnego złożenia w domu. W wymiarze politycznym prosumpcją może być włączanie w proces decyzyjny ludzi spoza systemu instytucjonalnego, czego przykładem mogło być spotkanie przedstawicieli Rady Ministrów z przedstawicielami środowisk związanych z Internetem w sprawie tzw. ustawy hazardowej.

Wraz z odchodzeniem od masowej produkcji zmienia się także poczucie czasu. Maszyny nie dyktują już rytmu pracy, maleje więc rola synchronizacji oraz co za tym idzie punktualności ${ }^{45}$. Coraz większą popularnością cieszą się portale internetowe udostępniające wybrane przez nas audycje - możemy je obejrzeć kiedy chcemy, niezależnie od programu telewizyjnego. Powinno to także oznaczać większą popularność takich portali wśród potencjalnych wyborców Platformy Obywatelskiej.

\footnotetext{
${ }^{42}$ A. Toffler, Trzecia..., op. cit., s. 283.

${ }^{43}$ Ibidem, s. 391.

${ }^{44}$ Ibidem, s. 405-407.

45 Ibidem, s. 377.
} 
Miejsca trzeciej fali ustępuje także maksymalizacja ${ }^{46}$. Zmiany w tym zakresie możemy przedstawić na przykładzie ewolucji w podejściu do sił zbrojnych RP. Zgodnie z industrialnym podejściem o ich sile powinna decydować liczebność - im wyższa liczba żołnierzy tym silniejsze jest wojsko. Przeprowadzona przez Platformę Obywatelską reforma, zakłada odejście od poboru na rzecz żołnierzy kontraktowych - per saldo zmniejszy się jednak liczba żołnierzy.

Coraz częściej krytyce poddawani są specjaliści. Dominują hasła związane z prowadzeniem konsultacji społecznych oraz dopuszczaniem laików do podejmowania decyzji, które do niedawna były zarezerwowane dla wąskiej grupy specjalistów ${ }^{47}$. Przykładem może być sposób podjęcia decyzji przez Prezydenta Miasta Stołecznego Warszawy o umiejscowieniu pomnika upamiętniającego katastrofę smoleńską poprzez sondaż na dużej próbie, zamiast zasięgnięcia opinii historyków sztuki, konserwatorów zabytków czy architektów.

Cywilizacja trzeciej fali to także zanegowanie przejawiającej się we wszystkich sferach życia koncentracji ${ }^{48}$. Objawia się ona zarówno w odpływie mieszkańców z centrów miast na jego obrzeża oraz coraz chętniejszemu dzieleniu się władzą w partii. Krótka analiza statutów PO i PiS, jasno wskazuje na zdecydowanie większą koncentrację władzy tej drugiej. Odejście od automatycznej centralizacji wszystkich struktur jest już tylko skutkiem zakwestionowania zasady standaryzacji, synchronizacji, koncentracji, maksymalizacji i specjalizacji ${ }^{49}$. Trzecia fala nie jest jednak prostym zaprzeczeniem zasady centralizacji. Zakłada ona raczej jej elastyczne stosowanie, niczym drużyna futbolowa, która na dźwięk gwizdka potrafi przejść z jednej formacji do drugiej ${ }^{50}$. Ten styl myślenia będzie zatem popierać decentralizację i zasadę subsydiarności w działaniu samorządu terytorialnego.

Wyżej opisane procesy spowodowały także kryzys instytucji społecznych drugiej fali. Przeformułowaniu uległa przede wszystkim rodzina. $\mathrm{Z}$ jednej strony jest ona wspierana przez stopniowo przenoszenie pracy do domu, z drugiej strony zmienia się jej skład. Coraz popularniejszym stylem życia jest pozostanie singlem. Możliwe są także rodziny złożone z dziecka i tylko jednego z rodziców, związki homosek-

\footnotetext{
${ }^{46}$ Ibidem, S. 402.

47 Ibidem.

${ }^{48}$ Ibidem.

49 Ibidem, s. 394.

5o Ibidem, s. 403-404.
} 
sualne czy rodzina atomowa powiększona o członków spoza rodziny ${ }^{51}$.

Poważny kryzys dotknął także instytucję korporacji. Są one dzisiaj powszechnie krytykowane, co szczególnie charakterystyczne, nie ze względu na cel, którym do tej pory była maksymalizacja zysku, ale ze względu na inne aspekty jej działalności. Tak więc społeczeństwa trzeciej fali wymagają od korporacji także dbałości o ochronę środowiska, rezygnacji z narzucanego pracownikom wyniszczającego trybu pracy czy ze współpracy z władcami państw o reżimie niedemokratycznym ${ }^{52}$. Ostrożny stosunek do dużych korporacji połączony ze wspieraniem małej i średniej przedsiębiorczości byłby zatem najlepszą rekomendacją dla partii politycznych, które chcą być kojarzone z trzecią falą.

Z. Bauman o postindustrializmie pisze także, że jest to koniec wiary w osiągnięcie stanu doskonałości. Niemożliwe zatem będą wszystkie projekty polityczne, które zapowiadają dojście do utopiii³ ${ }^{53}$ A. Toffler wprowadza pojęcie praktopii, czyli stanu lepszego od obecnego, nie będącego jednocześnie ani utopią ani antyutopią ${ }^{54}$. Tłumaczy to większe zainteresowanie PiS projektem IV Rzeczypospolitej niż dzieje się to w przypadku Platformy Obywatelskiej.

Możemy stwierdzić, że wojna polsko-polska, jest zjawiskiem realnym, którego przyczyny leżą po stronie wielkiego cywilizacyjnego kryzysu, w którym się znajdujemy. Istotą wojny polsko-polskiej jest opisana przez A. Tofflera „Superwalka”, z tym jednak zastrzeżeniem, że trzecia fala znajduje się jeszcze w fazie płynnej nowoczesności. „Superwalka" będzie się zaostrzała wraz z przejmowaniem przez przeciwników drugiej fali kolejnych cech trzeciej fali. Należy także zwrócić uwagę, iż w związku z przyspieszeniem nadchodzenia kolejnych fal, możemy także być jeszcze świadkami nadejścia czwartej fali.

\section{SUMMARY}

The author Presents the Polish - Polish war issue by using the postindustrial crisis theory. He concentrates on the A. Toffler's theory of the Second and Third Wave and on the term of Superfight. According to the author, the two sides of Polish - Polish war are the supporters of both the Second Wave and the Liquid Modernity. Polish - Polish war

\footnotetext{
${ }^{51}$ Ibidem, s. 331.

${ }^{52}$ Ibidem, s. 359-360.

${ }^{53}$ Z. Bauman, Ptynna..., op. cit., s. 46.

${ }^{54}$ A. Toffler, Trzecia..., op. cit., s. 537.
} 
will be increasing while supporters of the Liquid Modernity accept the ideas accurate for the Third Wave.

\section{Nota O AUTORZE}

Jacek Mazurczak [jacek.mazurczak@gmail.com] - absolwent politologii na Wydziale Nauk Politycznych i Dziennikarstwa UAM oraz student europeistyki w Centrum Europejskim Uniwersytetu Warszawskiego. Jego zainteresowania badawcze oscylują wokół zagadnień związanych z kryzysem postindustrialnym, organizacjami pozarządowymi w stosunkach międzynarodowych, prawami człowieka drugiej generacji oraz polityką Unii Europejskiej wobec krajów rozwijających się. 
